\title{
Changes in the Relationship Between Formal Education and Formal Employment Sector in Nepal Between 1995 and 2014
}

\author{
Thomas Bolli ${ }^{1 *}$ (i) Mahesh Nath Parajuli ${ }^{2}$, and Ursula Renold ${ }^{3}$ \\ ${ }^{1 \& 3}$ Department of Management, Technology, and Economics, ETH Zurich, Zurich, \\ Switzerland \\ ${ }^{2}$ School of Education, Kathmandu University, Kathmandu, Nepal
}

\begin{abstract}
This paper uses seven individual-level surveys between 1995 and 2014 to analyse the hypothesis that formal education increases wage-employment and formal sector employment in Nepal. The results show that formal education has increased substantially. However, formal sector employment has remained relatively stable. Individuals with tertiary education are about twice as often employed in the formal sector than individuals without completed primary education. This relationship is less strong for secondary education (22\%) and primary education (7\%). The results further show that about half of the relationship arises from working in governmentrelated sectors. The overall picture regarding the relationship between formal education and formal sector employment has remained similar over time. However, the strength of the relationship between completed primary and secondary education and formal sector employment has decreased over time. The relationship between tertiary education and formal sector employment has remained stable unless the government related sectors are excluded.
\end{abstract}

Keywords: formal education, informal sector, informal employment, selfemployment, Nepal

* Corresponding Author.

(1) thomas.bolli@mtec.ethz.ch
ISSN: 2091-0118 (Print) / 2091-2560 (Online)

(C) 2019 The Author(s).

Journal homepages: ${ }^{1}$ http://www.kusoed.edu.np/journal/index.php/je

${ }^{2}$ https://www.nepjol.info/index.php/JER/index

Published by Kathmandu University School of Education, Lalitpur, Nepal.

This open access article is distributed under a Creative Commons Attribution (CC BY-SA 4.0) license. 


\section{Introduction}

A large literature discusses various goals of education systems. A prominent example is Klieme et al. (2006), who differentiates three goals of education systems, namely providing human capital for the production processes, enabling individuals to govern the course of their lives, and contributing to civic society. Even though many authors highlight the relevance of taking a holistic perspective of formal education (see, e.g., Parajuli, 2014), this paper focuses on the human capital function of formal education systems, because increasing human capital plays a critical role to reduce poverty and increase the living standard in Nepal (see, e.g., Hanushek \& Woessmann, 2008; Krueger \& Lindahl, 2001). This is particularly true for rural areas of Nepal (see, e.g., Sharma, 2014), where educational attainment lags substantially.

Reaping the benefits of formal education in terms of growth requires an environment that rewards human capital sufficiently. However, while the meta-analytical study of Van der Sluis, Van Praag, and Vijverberg (2005) suggests that formal education increases formal economic activity measured by wage-employment in developing countries, no evidence exists for Nepal. The most relevant literature provides descriptive statistics of formal employment (Jah, 2002; Central Bureau of Statistics [CBS], 1999, 2009). Hence this paper analyses the relationship between formal educational attainment in terms of the ISCED categories - primary, secondary and tertiary education - and formal economic activity measured by wage employment and formal sector employment. Using seven data sets across time further allows us to assess how the relationship between formal education and formal economic activity has changed between 1995 and 2014.

The second section of the paper develops the hypotheses based on the existing literature regarding formal education and formal sector employment. The third section describes the data sources and empirical methodology. The fourth section shows the results that are discussed in the fifth section. The sixth section summarises the findings and draws conclusions.

\section{Literature Review and Hypotheses}

The argument to develop a hypothesis regarding the relationship between formal education and formal sector employment builds on the literature analysing the returns to formal education. Particularly relevant is the literature that compares the returns to Journal of Education and Research, Vol. 9, No. 2, 2019 
Formal Education and Formal Employment in Nepal $\mid 51$

formal education for self-employed and wage-employed workers (see, e.g. Fossen \& Büttner, 2013). This literature builds on two main theoretical arguments. First, the human capital theory argues that formal education improves productivity, thereby increasing wages of workers (see, e.g. Becker, 1962). Second, the signalling theory argues that because acquiring formal education is costly, formal education degrees signal high individual productivity (see, e.g., Spence, 1973). Hence, the signalling theory argues that returns to formal education arise because formal education represents a signalling device in labour markets with imperfect information rather than because formal education creates productivity improvements.

Assuming that self-employed are not subject to screening, combining these two theories suggests that returns to formal education are higher for wage-employed than for self-employed (see, e.g., Brown \& Sessions, 1999; Wolpin, 1977). The reason is that self-employed workers benefit from productivity increases, but have no benefit from the signal. Wage-employed workers, on the other hand, enjoy both productivity increases and signalling benefits. This would suggest that educated persons select into wage-employment, indicating a positive relationship between formal education and wage-employment.

However, other authors argue that customers use formal education as a screening device (see, e.g., Backes-Gellner \& Werner, 2007, Parker \& Van Praag, 2006). Furthermore, the personal control theory argues that organizational constraints restrict self-employed less in the use of their human capital than wage-employed. Hence, selfemployed workers can employ their human capital more effectively (see, e.g., Douhan \& Van Praag, 2009; Van Praag, Van Witteloostuijn, \& Van der Sluis, 2013). These constraints can either stem from the company or government regulations (De Soto, 1989). These two arguments indicate a neutral or negative relationship between formal education and wage-employment.

Since theoretical arguments go both ways, a theoretical framework remains ambiguous regarding the relative return of formal education for self-employed and wage-employed workers, respectively, and hence regarding the relationship between formal education and wage-employment. This theoretical ambiguity is supported by empirical ambiguity of the literature review of Dickson, Solomon, and Weaver (2008) and Van der Sluis, Van Praag, and Vijverberg (2008). Furthermore, recent literature 
recognizes the heterogeneity of the informal sector (see, e.g., Amin, 2010; Falco, Kerr, Rankin, Sandefur, \& Teal, 2011; Günther \& Launov, 2012). These papers argue that some workers are active in the informal sector due to necessity, while others choose the informal sector voluntarily because it provides more opportunities (Fossen \& Büttner, 2013). However, the meta-analytic study of Van der Sluis et al. (2005) suggests, that the relationship between formal education and wage-employment for developing countries is positive on average. Based on this empirical evidence, we hypothesize that

H1: Higher formal educational attainment increases the probability to be wageemployed rather than self-employed.

H2: Higher formal educational attainment increases the probability to work in the formal sector.

\section{Data and Methodology}

This section describes the data and methodology of this paper. It starts by describing the data sources, followed by a description of the measures for informal sector activity and formal education. Finally, the section discusses the statistical methodology used in the paper.

\section{Data Sources}

The empirical analysis uses seven surveys of individuals conducted by CBS, Nepal. The seven surveys can be separated into three types of surveys or data sources. First, the Nepal Living Standard Surveys (NLSS) refer to the years 1995/1996, 2003/2004, 2010/2011, respectively (for more information, see CBS, 1996, 2004, 2011). Second, the Nepal Labour Force Surveys refer to the years 1998/1999 and 2008, respectively (for more information, see CBS, 1999, 2009). Third, the Annual Household Surveys refer to the years 2013/2014, 2014/2015, respectively (for more information, see CBS, 2015, 2016). ${ }^{1}$

The different data sources differ regarding available information and sample size. Restricting the sample to individuals aged between 25 and 65 and dropping observations with missing values in labour market status yields 96’359 observations. Further restricting the sample to individuals working in the non-agricultural sector without missing values regarding formal education, gender, age, living district, selfemployment and formal sector employment yields a total sample of 31'599 for self-

Journal of Education and Research, Vol. 9, No. 2, 2019 
Formal Education and Formal Employment in Nepal | 53

employment or 24'186 observations for formal sector employment. The samples are substantially larger for the Nepali Labour Force Surveys in 1998 (N=23,203) and 2008 $(\mathrm{N}=24,991)$ than in the NLSS and AHHS that have between 3,500 to 10,000 observations each year. This matters for two reasons. First, in order to ensure sufficient sample size, the descriptive statistics of differences across industries use cross-sectional weights to calculate averages across years. Hence, these differences are mainly driven by the years 1998 and 2008. Second, we report estimates of the relationship between formal education and informal activity measures that control for the data source. These results show changes over time within the data sources. Hence, these specifications test for a potential bias arising from variation in the sample size or methodology across data source.

\section{Measurement of Informal Economic Activity}

For our analysis, we need to measure informal economic activity. However, though Hart (1973) has sparked substantial literature on informal economic activity, a uniform definition of the term "informal economic activity" does not exist. International Labour Organization (ILO) broadly describes informal sector employment as jobs in informal sector companies, which consist of small, private, unincorporated companies engaged in non-agricultural activities meant for sale or barter (ILO, 2013). Building on this general description, the literature proposes several empirical measures of formal and informal economic activity (see, e.g., CBS, 2009; Hussmanns, 2004; ILO, 2013).

The early literature suggests a very simple measure of informal economic activity that refers to the distinction between wage-employed and self-employed workers in the non-agricultural sector. Figure 1 exploits the simplicity of this measurement approach to illustrate how the activity patterns of the Nepali population aged 25 to 65 changed between 1995 and 2014. The results suggest that about $11 \%$ of the population are not in the labour force and that this value has remained stable across time. Similarly, unemployment is scarce at about $1 \%$ in all of the years. In $1995,71 \%$ of the population worked in the agricultural sector. This value dropped continuously, reaching $60 \%$ in 2014. This finding reflects a substantial structural change in the Nepali economy. Hence, the share of the population working in the non-agricultural sector has increased substantially from $17 \%$ in 1995 to $25 \%$ in 2014 . However, the share of self-employed within this sub-population has remained roughly constant at about $50 \%$. 


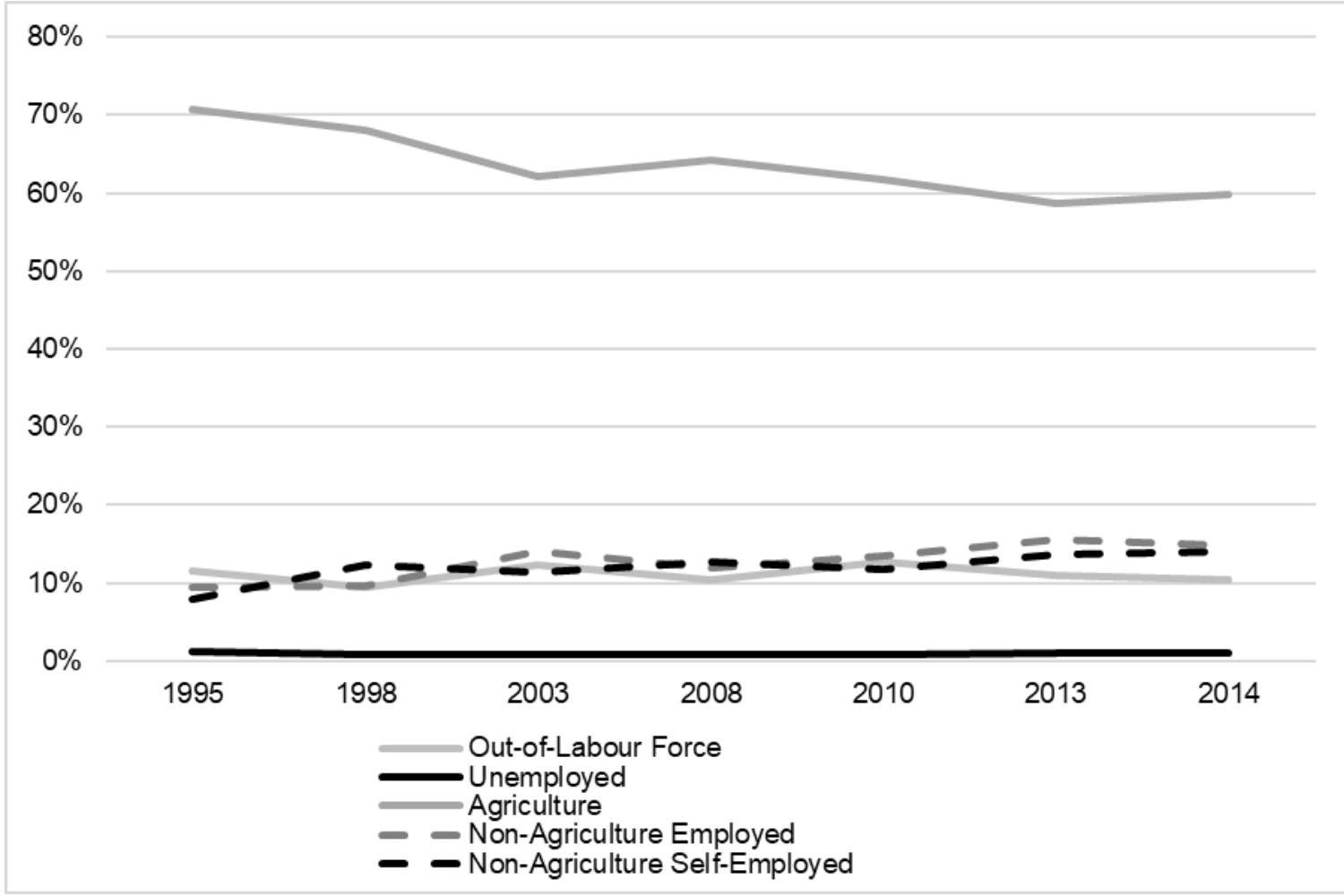

Notes: The figure displays the weighted activity shares of the population aged 25 to 65 . Source: Own calculations based on NLSS 1995/1996, 2003/2004, 2010/2011, NLFS 1998/1999, 2008, AHHS 2013/2014, 2014/2015. N=96’359.

Figure 1. Development of activity patterns over time.

Since the self-employment represents a relatively crude measure of the informal sector (see, e.g., Henley, Arabsheibani, \& Carneiro, 2009; Yu, 2012), Table 1 illustrates that the more recent literature uses a more refined measure of the informal sector is based on three conditions (CBS, 2009; Hussmanns 2004), namely employment status, company registration and company size. Hence, using all three conditions suggests that the informal sector refers to a) paid employees in unregistered companies with less than ten employees and to b) self-employed workers or contributing family members in companies with less than ten employees. All other employees work in the formal sector. $^{2}$

Journal of Education and Research, Vol. 9, No. 2, 2019 
Table 1

Measurement of Informal Sector

\begin{tabular}{lll}
\hline Employment status & \& Company registration & \& Company size \\
\hline Paid employee & Unregistered company & Less than 10 \\
Self-employed or & & Less than 10 \\
contributing family & & \\
member & & \\
\hline
\end{tabular}

(Source: Own depiction based on Hussmanns, 2004)

Figure 2 displays the shares of informality based on these two measures in the years 1995, 1998, 2003, 2008, 2010, 2013 and 2014. The share of self-employed is substantially lower (49\% on average) than the measure of the informal sector that additionally accounts for whether the employer is a registered company and the size of the employer ( $67 \%$ on average).

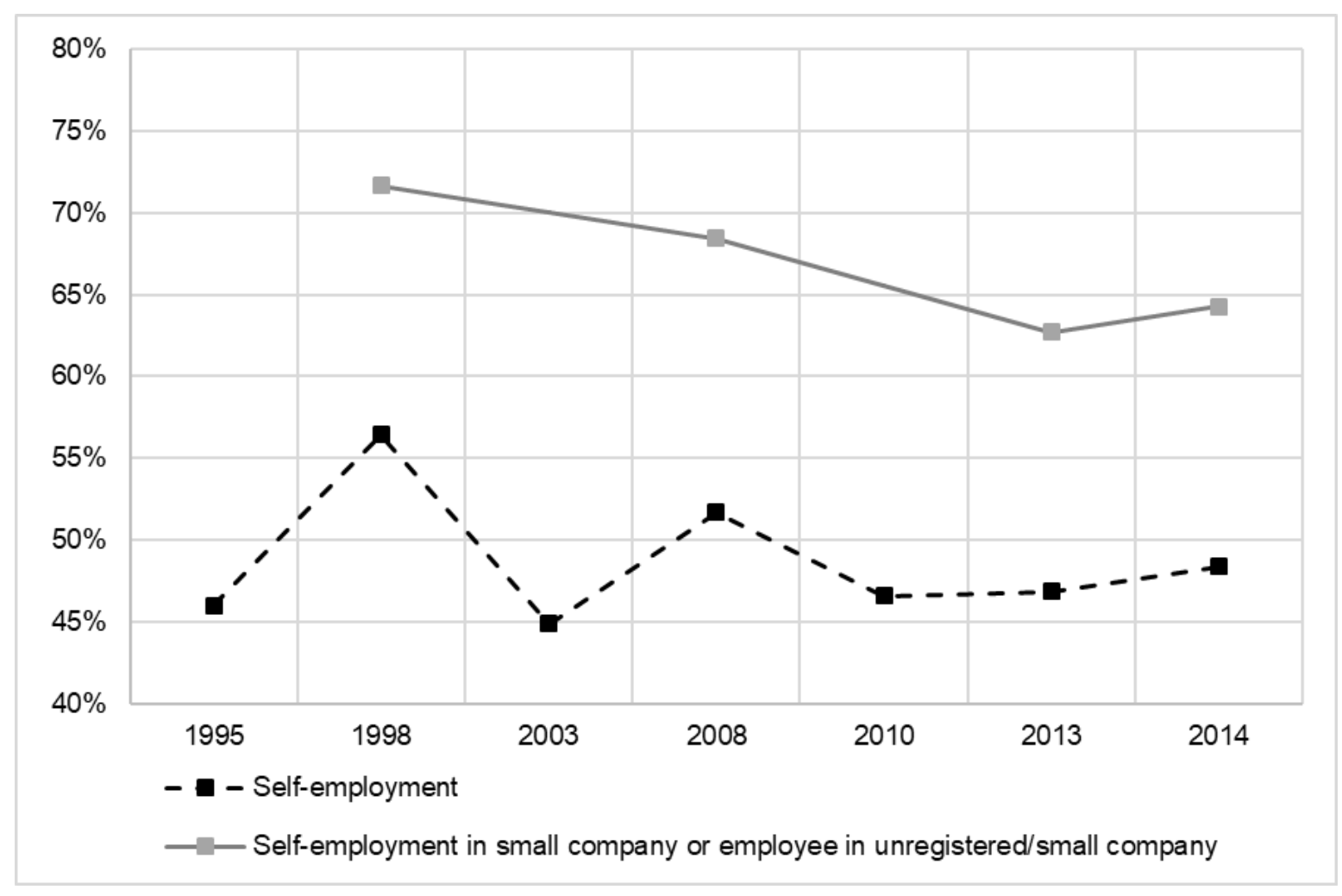

Journal of Education and Research, Vol. 9, No. 2, 2019 


\section{$56 \mid$ T. Bolli, M. N. Parajuli, \& U. Renold}

Notes: The figure displays the weighted share of self-employment and informal sector share in the population aged 25 to 65 that is working in the non-agricultural sector. Source: Own calculations based on NLSS 1995, 2003, 2010, NLFS 1998, 2008, AHHS 2013, 2014. Values without a marker represent linear interpolations. N=31'599, 24'189.

Figure 2. Development of informality over time.

\section{Measurement of Formal Education}

Formal education, the main explanatory variable, refers to four categories, namely individuals without primary education and individuals with completed primary, secondary and tertiary education, respectively. Figure 3 shows the development of formal education shares in the Nepali population aged 25 to 65 between 1995 and 2014.

In 1995, most of the population had not finished primary education (83\%) and the shares of completed primary, secondary and tertiary education amounted to only $7 \%$, $9 \%$ and $1 \%$, respectively. This pattern has substantially changed in the following 20 years, reflecting substantial progress of Nepal in providing formal education to the population. By 2014, the population share without completed primary education dropped to $68 \% .10 \%$ have finished a primary education, corresponding to an annual growth of about $0.2 \%$. The strongest growth of annually $0.7 \%$ happened in the share with secondary education, which reached $18 \%$ in 2014 . The share of tertiary education increased by $0.1 \%$ per year, ending up at $3 \%$ of the population. Hence, even though growth rates have been substantial, the majority of Nepali still has not finished primary education and the share of tertiary educated Nepali remains very low. 


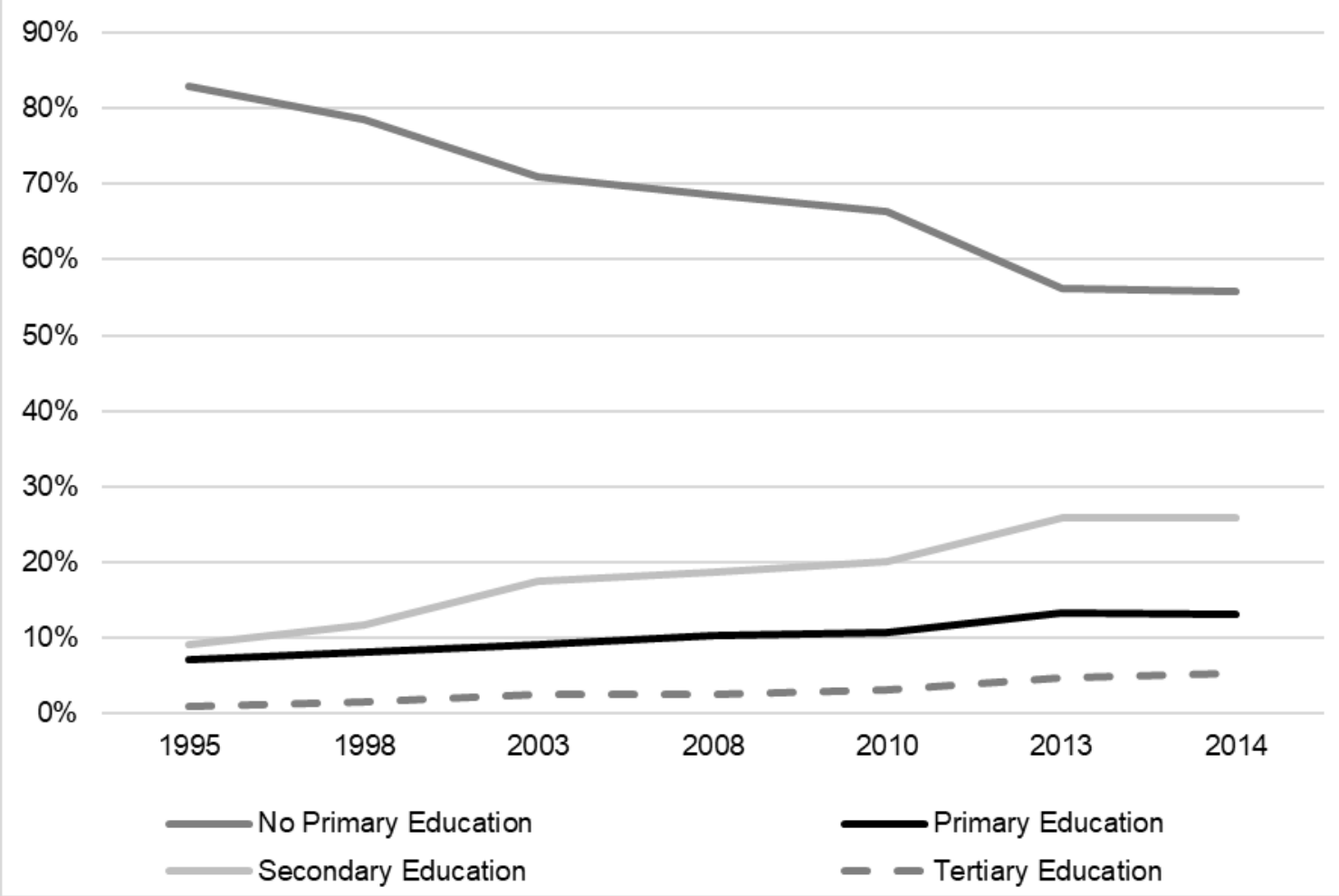

Notes: The figure displays formal education shares of the population aged 25 to 65 using cross-sectional weights to average across years. Source: Own calculations based on NLSS 1995/1996, 2003/2004, 2010/2011, NLFS 1998/1999, 2008, AHHS 2013/2014, 2014/2015. N=95,854.

Figure 3. Development of formal education.

Figure 4 illustrates the differences in formal educational attainment across economic sectors. The results show that the formal educational attainment allows to broadly separate economic sectors into three groups. First, agriculture has highest share of workers with no primary education. Similarly, the share of workers with no primary education is particularly high in the sectors mining, construction and other activities. Second, the sectors manufacturing, recycling, trade, hotels, and transport represent a group of sectors with moderate formal education levels. Third, the share of workers without primary education is very low in other services and the government-related sectors public administration, education and health. Particularly striking is the high share of workers with tertiary education in these sectors, ranging between $21 \%$ and 
$58 \mid$ T. Bolli, M. N. Parajuli, \& U. Renold

$36 \%$. Comparing this to the population average of $3 \%$ reveals that these four sectors absorb the majority of tertiary educated workers. Furthermore, recycling and trade also display shares of about $6 \%$ of workers with tertiary education.

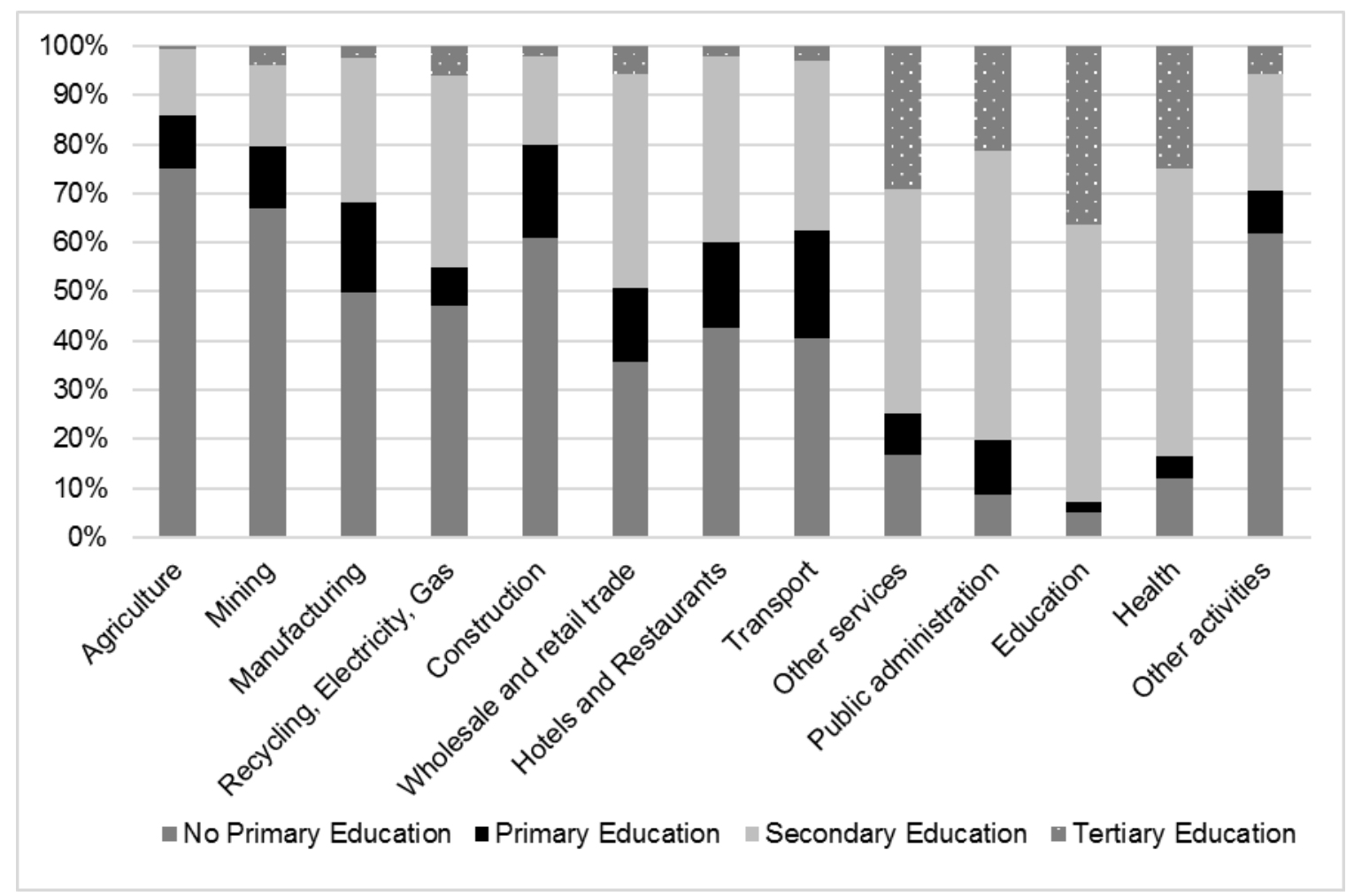

Notes: The figure displays the formal education shares of the working population aged 25 to 65 using cross-sectional weights to average across years. Source: Own calculations based on NLFS 1998/1999, 2008, AHHS 2013/2014, 2014/2015. $\mathrm{N}=59^{\prime} 870$.

Figure 4. Heterogeneity of formal education across economic sectors.

\section{Empirical Methodology}

To analyse the relationship between formal education and the formal employment sector, we estimate multivariate models that explain self-employment and formal sector employment by formal education and time.

Journal of Education and Research, Vol. 9, No. 2, 2019 
Formal Education and Formal Employment in Nepal | 59

We use two dependent variables, $y$. The first measures whether an individual is wage-employed rather $(\mathrm{y}=1)$ than self-employed $(\mathrm{y}=0)$. This is denoted as wageemployment. The second measure additionally considers employed workers in unregistered or small companies (less than ten workers) and self-employed workers in small companies as informal sector workers. In the following text, this measure is denoted formal sector employment. Both of these variables are binary, meaning that they take values 0 and 1 , respectively. Therefore, we estimate probit models. To account for potential heteroscedasticity of the error-term, $\varepsilon$, we report robust standard errors. ${ }^{3}$

In order to test hypothesis 1 and 2, we estimate the following model

$$
y_{i}=\propto+\beta_{1} Y E A R+\beta_{2} E D U_{i}+\gamma X_{i}+\varepsilon_{i},
$$

where the index i denotes the individual. EDU is a vector of three dummy variables indicating whether the highest formal educational attainment of an individual is primary, secondary or tertiary education, respectively (see, e.g., Chair of Education Systems, 2015, for more information about the Nepali education system). Individuals without completed primary education represent the baseline category.

We are interested in how formal education affects wage-employment and formal sector employment. However, due to the non-linearity of probit estimations, the coefficients $\beta 2$ do not reflect the effects of interest directly. Therefore, we report the average marginal effects that reflect the effect of education on the probability to be in wage-employment and formal sector employment, respectively. ${ }^{4}$ These average marginal effects allow testing hypothesis $\mathrm{H} 1$ and $\mathrm{H} 2$, which suggest that formal education increase wage-employment and formal sector employment, respectively.

The vector of control variables, $\mathrm{X}$, includes gender, age, age squared, and district fixed effects. ${ }^{5}$ In addition, we include a fixed effect for each year (YEAR). Note that the estimations still represent correlations rather than causal effects and should be interpreted accordingly. For example, we lack data about measures that capture human capital that is acquired outside of the formal education system, such as non-formal and informal learnings. This so-called non-formal skill development through courses may have an impact. Similarly, we have no information about whether formal sector employment represents a choice of the individual or the company. 
To analyse how the effect of education has changed over time, we estimate two model specifications that differ in terms of the functional form of time. The first approach is very general and includes a fixed effect for each year for which data exists (YEAR) as well as an interaction term between education and year (EDU*YEAR). These interaction terms allow estimating how the relationship between education and the dependent variable for each year. The resulting estimation can formally be written as:

$$
y_{i}=\propto+\beta_{1} Y E A R+\beta_{2} E D U_{i}+\beta_{3} E D U_{i} * Y E A R+\gamma X_{i}+\varepsilon_{i},
$$

Modelling time by year fixed effects and their interaction with education has the benefit that the model allows to understand the development over time in detail. However, it remains unclear how to test in a formal statistical way whether the marginal effects have changed over time. This challenge arises for three reasons. First, the question arises which marginal effects should be compared. Second, the availability of data sources differs across time. Therefore, we need to account for the data source in terms of survey methodology and sample size. Third, including year as a continuous variable is challenging because estimating marginal effects of interaction terms of continuous variables in probit estimations is non-trivial (Ai \& Norton, 2003).

Due to these reasons, we complement the estimations based on year fixed effects with estimates for whether the relationship between formal education, self-employment and formal sector employment is different after 2008 than before 2008. The cut-off year is chosen in a way that the data sources NLSS and the NLFS provide observations before and after the cut-off year, allowing to include fixed effects for the data source. Formally, we estimate the following probit estimation with robust standard errors:

$$
y_{i}=\propto+\beta_{1} 2008+\beta_{2} E D U_{i}+\beta_{3} E D U_{i} * 2008+\gamma X_{i}+\varepsilon_{i},
$$

2008 denotes a dummy variable taking the value 0 before 2008 and 1 afterwards. Hence, the interaction of EDU and 2008 represents the change in the relationship between EDU and the dependent variable before and after the year 2008. This simple approach allows assessing directly whether marginal effects have changed over time. Furthermore, it allows including dummies for the data source, thereby accounting for potential differences in survey methodology and sample size. ${ }^{6}$ 
Formal Education and Formal Employment in Nepal | 61

\section{Empirical Results}

This section discusses the empirical results regarding the relationship between formal education, self-employment and formal sector employment. Table 2 shows the average relationship between formal education, wage employment, and formal sector employment based on formula (1). Based on formula (2), Figures 5 and 6 display yearly marginal effects of formal education on wage-employment and formal sector employment, respectively. ${ }^{7}$ Based on formula (3), Table 3 tests formally whether the marginal effects changed between the period before 2008 and thereafter. Furthermore, Table 3 analyses the effect of excluding government sectors.

Table 2

Average Relationship Between Formal Education and Formality

\begin{tabular}{ccccc}
\hline Sample & \multicolumn{2}{c}{ Full Sample } & \multicolumn{2}{c}{ Excluding government related sectors } \\
\hline $\begin{array}{c}\text { Dependent } \\
\text { Variable }\end{array}$ & Wage employment & $\begin{array}{c}\text { Formal sector } \\
\text { employment }\end{array}$ & Wage employment & $\begin{array}{c}\text { Formal sector } \\
\text { employment }\end{array}$ \\
\hline Primary education & $-0.026 * * *$ & $0.074 * * *$ & $-0.057 * * *$ & $0.030^{* * *}$ \\
Secondary & $(0.009)$ & $(0.009)$ & $(0.009)$ & $(0.009)$ \\
education & 0.009 & $0.222 * * *$ & $-0.104 * * *$ & $0.077 * * *$ \\
Tertiary education & $(0.007)$ & $(0.007)$ & $(0.007)$ & $(0.007)$ \\
& $0.228 * * *$ & $0.474 * *$ & $0.046 * *$ & $0.249 * *$ \\
$\mathrm{~N}$ & $(0.010)$ & $(0.009)$ & $(0.011)$ & $(0.010)$ \\
& 31599 & 24186 & 27598 & 20143 \\
\hline
\end{tabular}

Notes: The table displays marginal effects and robust standard errors of a probit estimation for wage employment and formal sector employment. Columns 2 and 3 show the results for the full sample, while columns 4 and 5 show the results excluding individuals working in the government-related sectors. $*, * *$ and $* * *$ refer to significance on the $10 \%, 5 \%$ and $1 \%$ level, respectively. Each panel of primary, secondary and tertiary education shows the effect of formal education based on $\beta_{2}$ in formula (1). No completed primary education is the baseline category. All estimates control for gender age, age squared, district fixed effects, and year fixed effects.

Table 2 shows that completed primary and secondary education has no or even a small negative effect on wage-employment. These results fail to support hypothesis 1 . This might be due to a lacking link between actors from the education and employment system (Bolli et al., 2018). Figure 5 shows that the effects of primary and secondary education appear to decrease over time. This finding is supported by the formal test in 


\section{$62 \mid$ T. Bolli, M. N. Parajuli, \& U. Renold}

Table 3. In the period before 2008, the effect for both formal education categories has decreased.

Tertiary education, on the other hand, has a positive relationship with wageemployment. Having completed tertiary education increases the probability of wageemployment by about $23 \%$, thereby supporting hypothesis 1 . Figure 5 further suggests that the strength of the relationship has decreased over time. The formal test in Table 3 confirms that the marginal effect of tertiary education is lower after 2008 than before.

Hence, the results show that the overall picture has remained similar within the analysed time. However, the strength of the relationship between formal education and wage-employment has decreased slightly.

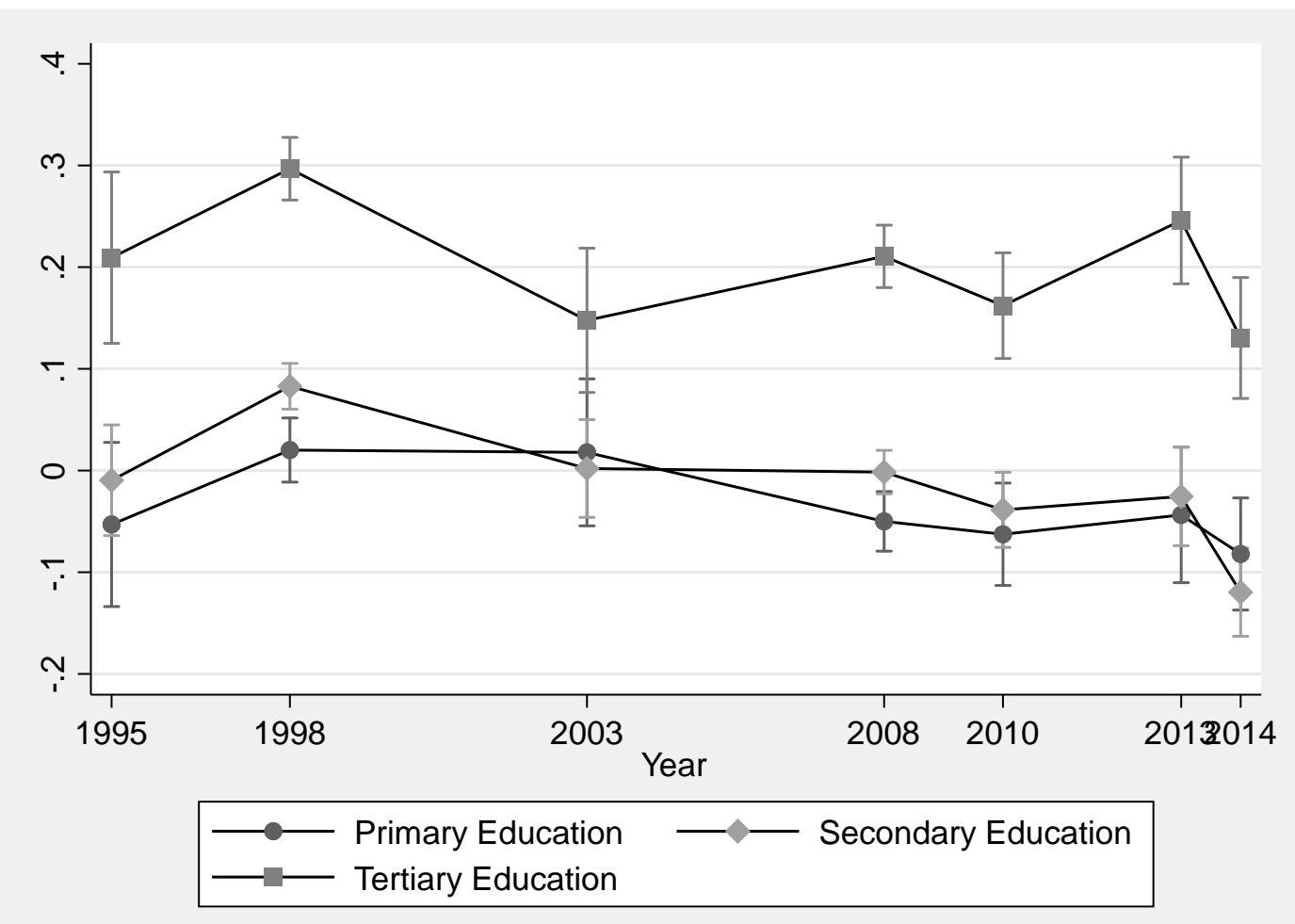

Notes: The figure displays the effect of attaining primary, secondary and tertiary education relative to no formal education on the probability to be wage-employed rather than self-employed for the population aged 25 to 65 working in the non-agricultural 
Formal Education and Formal Employment in Nepal | 63

sector. The marginal effects and $95 \%$ confidence intervals are based on coefficient estimates of $\beta_{2}$ and $\beta_{3}$ and the corresponding robust standard errors of probit estimations defined in formula (2). Estimates further control for gender, age, age squared, district, and year fixed effects. Source: Own calculations based on NLSS 1995/1996, 2003/2004, 2010/2011, NLFS 1998/1999, 2008, AHHS 2013/2014, 2014/2015. N=31’599.

Figure 5. Relationship between formal education and wage-employment.

Table 2 also displays the average marginal effects of formal education on formal sector employment. The results in terms of the average effect differ substantially from the estimates using wage-employment as the dependent variable. Concretely, completed primary education increases formal sector employment, though only by about $7 \%$. Furthermore, secondary education has a strong positive relationship with formal sector employment, increasing it by about $22 \%$ on average. Finally, completed tertiary education improves the probability of formal sector employment by about $47 \%$ on average. Hence, these results support hypothesis 2 , suggesting that formal education increases formal sector employment.

Figure 6 shows that the results regarding the development of the effects over time are similar between estimates using wage-employment and formal sector employment as the dependent variable. The overall picture has remained similar. However, the relationship between formal education and formal sector employment has decreased slightly. Concretely, the effect of both primary and secondary education has been seven to eight per cent higher before 2008 than thereafter.

However, this result is less clear-cut for tertiary education, for which Figure 6 displays a statistically insignificant and fairly stable effect. The stability of the relationship between tertiary education and formal sector employment might be related to the finding of Figure 4 that employment of workers with tertiary education is strongly concentrated in the government-related sectors public administration, education and health. The right part of Table 3 analyses this question by estimating the relationship between formal education and formal sector employment for individuals that are not working in these government-related sectors. The results support the interpretation that the stable relationship between tertiary education and formal sector employment is due to government-related sector. Concretely, the results show that the 


\section{$64 \mid$ T. Bolli, M. N. Parajuli, \& U. Renold}

relationship between tertiary education and formal sector employment also decreases overtime for a sample that excludes these three sectors.

The estimates in Table 2 excluding these three sectors further show that about half of the average relationship between formal education and formal sector employment arises due to these government-related sectors. For primary education, the effect size is reduced relatively slightly from $7 \%$ to $3 \%$. For secondary education, the magnitude of the relationship drops from $22 \%$ to $8 \%$ if the government related sectors are excluded. For tertiary education, the change is even more dramatic. The $47 \%$ effect size of tertiary education decreases to $25 \%$ after the exclusion of these three sectors. This shows that working in these sectors matters relatively little for individuals with primary education, but represents an important source of formal sector employment for individuals with secondary or tertiary education.

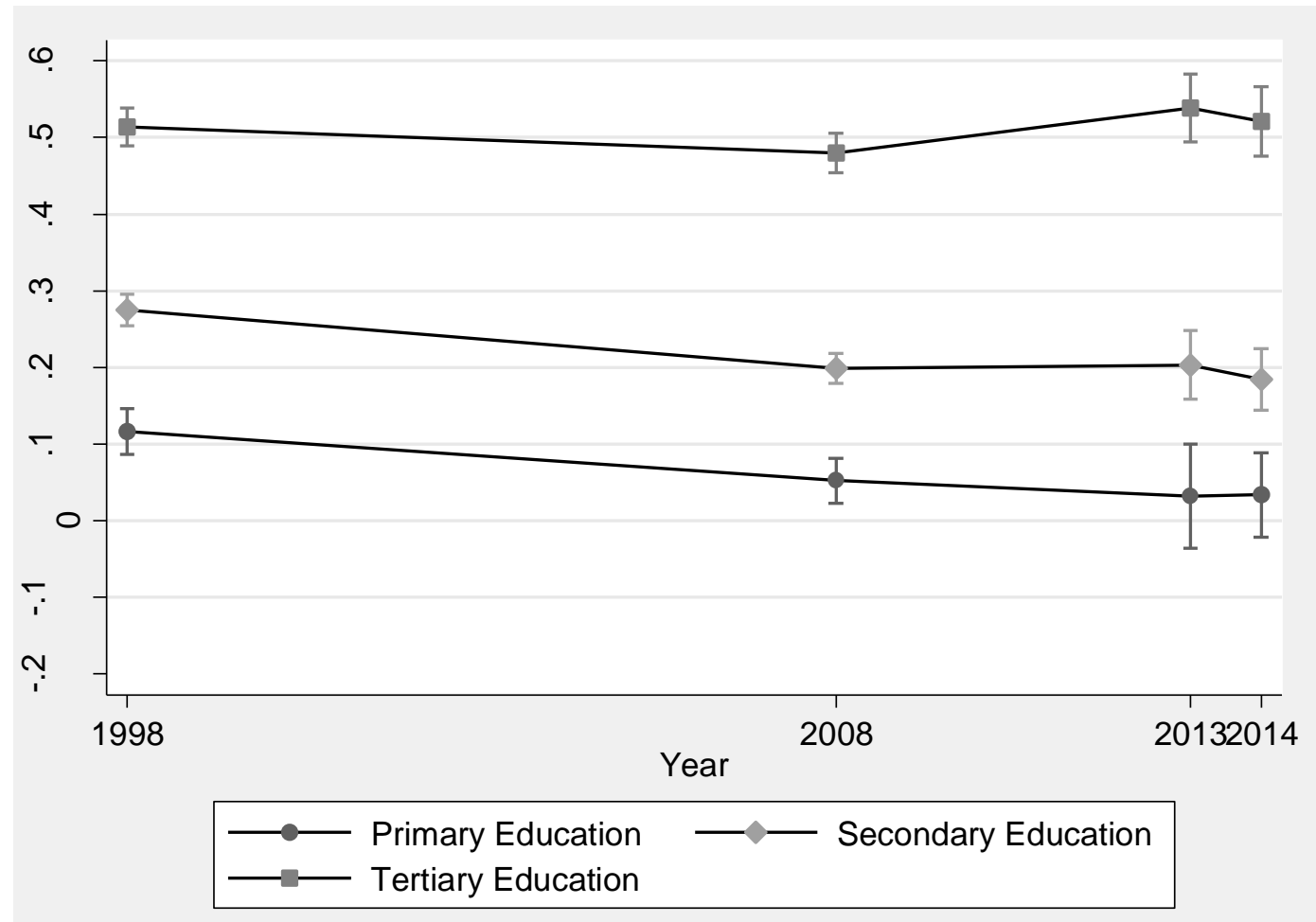

Notes: The figure displays the effect of attaining primary, secondary and tertiary education relative to no formal education on the probability to be in the formal 
employment sector for the population aged 25 to 65 working in the non-agricultural sector. The marginal effects and $95 \%$ confidence intervals are based on coefficient estimates of $\beta_{2}$ and $\beta_{3}$ and the corresponding robust standard errors of probit estimations defined in formula 2). Estimates further control for gender, age, age squared, district, and year fixed effects. Source: Own calculations based on NLFS 1998/1999, 2008, AHHS 2013/2014, 2014/2015. N=24'186.

Figure 6. Relationship between formal education and formal sector employment.

Analysing the difference between young (below 40) and old (above 40) individuals ${ }^{8}$ shows that the relationship between primary and secondary education and formal sector employment has decreased for both young and old over time. However, the results also show that the effect is stronger for the old regarding tertiary education.

Furthermore, looking at the changes in the estimates across time for men and women separately ${ }^{9}$, the results show that the developments are similar across gender regarding primary and secondary education. The relationship between tertiary education and wage-employment has also decreased for both men and women over time. However, the finding that tertiary education has remained stable regarding the measure of formal sector employment only holds for men. For women, the effect of tertiary education has decreased.

Table 3

Change in the Relationship between Formal Education and Formality over Time

\begin{tabular}{|c|c|c|c|c|c|c|}
\hline Dependent & \multicolumn{2}{|c|}{ Wage employment } & \multicolumn{2}{|c|}{ Formal sector employment } & \multirow{2}{*}{\multicolumn{2}{|c|}{$\begin{array}{l}\text { Formal sector excluding } \\
\text { government-related sectors }\end{array}$}} \\
\hline Variable & & & & & & \\
\hline $\begin{array}{c}\text { Estimation } \\
\text { Primary } \\
\text { education } \\
\end{array}$ & Baseline & Datasource & Baseline & Datasource & Baseline & Datasource \\
\hline Before 2008 & $\begin{array}{c}0.009 \\
(0.014)\end{array}$ & $\begin{array}{c}0.010 \\
(0.014)\end{array}$ & $\begin{array}{c}0.119 * * * \\
(0.015)\end{array}$ & $\begin{array}{c}0.119 * * * \\
(0.015)\end{array}$ & $\begin{array}{c}0.065 * * * \\
(0.016)\end{array}$ & $\begin{array}{c}0.065^{* * * *} \\
(0.016)\end{array}$ \\
\hline $\begin{array}{c}\text { Change after } \\
2008\end{array}$ & $\begin{array}{c}-0.061 * * * \\
(0.018)\end{array}$ & $\begin{array}{c}-0.065 * * * \\
(0.018)\end{array}$ & $\begin{array}{c}-0.071 * * * \\
(0.019)\end{array}$ & $\begin{array}{c}-0.074 * * * \\
(0.019)\end{array}$ & $\begin{array}{c}-0.052^{* * * *} \\
(0.019)\end{array}$ & $\begin{array}{c}-0.057 * * * \\
(0.019)\end{array}$ \\
\hline $\begin{array}{l}\text { Secondary } \\
\text { education }\end{array}$ & & & & & & \\
\hline Before 2008 & $0.060 * * *$ & $0.059 * * *$ & $0.275^{* * *}$ & $0.276^{* * *}$ & $0.119 * * *$ & $0.120 * * *$ \\
\hline
\end{tabular}


$66 \mid$ T. Bolli, M. N. Parajuli, \& U. Renold

\begin{tabular}{ccccccc}
\hline & $(0.010)$ & $(0.010)$ & $(0.010)$ & $(0.011)$ & $(0.011)$ & $(0.012)$ \\
Change after & $-0.085^{* * *}$ & $-0.086^{* * *}$ & $-0.075^{* * *}$ & $-0.080^{* * *}$ & $-0.061 * * *$ & $-0.067 * * *$ \\
2008 & $(0.013)$ & $(0.012)$ & $(0.013)$ & $(0.013)$ & $(0.014)$ & $(0.014)$ \\
Tertiary & & & & & \\
education & & & & & \\
Before 2008 & $0.263^{* * *}$ & $0.264 * * *$ & $0.514 * * *$ & $0.510^{* * *}$ & $0.341^{* * *}$ & $0.341^{* * *}$ \\
& $(0.014)$ & $(0.014)$ & $(0.012)$ & $(0.012)$ & $(0.022)$ & $(0.022)$ \\
Change after & $0.263^{* * *}$ & $0.264 * * *$ & $0.514 * * *$ & $0.510^{* * *}$ & $0.341 * * *$ & $0.341 * * *$ \\
2008 & $(0.014)$ & $(0.014)$ & $(0.012)$ & $(0.012)$ & $(0.022)$ & $(0.022)$ \\
N & 31599 & 31599 & 24186 & 24186 & 20143 & 20143 \\
\hline
\end{tabular}

Notes: Each column of the table displays marginal effects and robust standard errors of a probit estimation. Columns 2 and 3 show the results for wage-employment. Columns 4 and 5 show the results for formal sector employment. Columns 6 and 7 show the results for wage-employment excluding individuals working in the government-related sectors. Data-source columns further control for data source fixed effects (NLSS, NLFS, AHHS). $*, * *$ and $* * *$ refer to significance on the $10 \%, 5 \%$ and $1 \%$ level, respectively. Each panel of primary, secondary, and tertiary education shows the effect of formal education before 2008 in addition to the change, which refers to the difference between the effect before and after 2008. Concretely, the marginal effects for "Before 2008" are based on $\beta_{2}$ in formula (3). The marginal effects of "Change after 2008" are based on $\beta_{3}$ in formula (3). No completed primary education is the baseline category. All estimates control for gender age, age squared, district fixed effects and after 2008 fixed effects.

\section{Discussion of Results}

This paper uses individual-level data of the NLSS, NLFS and AHHS to describe how formal educational attainment has developed over time. Furthermore, the data allows comparing the shares of self-employment and formal sector employment. These measures differ substantially but suggest that the share has remained relatively stable at a high level over time.

The high relevance of self-employment and informal sector employment suggest that policy should aim to improve and strengthen the opportunities in the informal sector in a way that formal and informal sector can coexist and complement each other. This includes, for example, providing services offered by state or non-state agencies to the informal sector. Another example can be illustrated based on the informal workshops of Autovillage in Butwal. In order to strengthen this car repairing district and its employment opportunities, a solution would have to be found how to improve formal 
Formal Education and Formal Employment in Nepal | 67

education at upper secondary level by learning and working in the informal workshops of these repair shops.

Estimates of the relationship between formal education, self-employment and formal sector employment show a surprisingly low relationship between primary/secondary education and wage-employment, while the relationship is positive for tertiary education. However, all formal education levels increase the probability to be in the formal sector employment if company registration and size is accounted for.

This overall pattern has remained between 1995 and 2014. However, the relationship has weakened over time for workers with primary or secondary education. The results are less clear for tertiary education. This is because workers with tertiary education are heavily concentrated in government-related sectors. Excluding these sectors suggests that the relationship between tertiary education and formal sector employment has decreased over time as well.

In order to put the results into an international context, we can compare the results to the meta-analytic results of Van der Sluis et al. (2005). They find that completed primary, secondary or postsecondary formal education increases the probability of wage-employment by $21 \%, 35 \%$ and $69 \%$, respectively. Hence, the estimated results suggest that the relationship is slightly lower in Nepal than in the average study.

The paper highlights the relevance of formal education quality, which raises the issue of the federalization process. Concretely, following the acceptance of the new constitution in 2015, Nepal has adopted a federalized governance system, introducing seven provinces (Nepal Law Commission, 2015). In this process, the provinces and especially the local governments should receive more power and responsibility than before. To the extent that the federalization of power and responsibility increases the efficiency of formal education and includes procedures of recognition of prior learnings (see, e.g., European Training Foundation, 1999; Sharma, 2008; Kafle, 2013), this process has the potential to improve the quality of formal education. Though this process is still under construction (see, e.g. Caves \& Renold, 2018; Renold \& Caves, 2017; Renold, Bolli, \& Caves, 2018), this represents an important shift in th formal education policy. 


\section{Summary and Conclusion}

The results show that tertiary education has a positive relationship with wageemployment, but the relationship remains negligible for primary and secondary education. This might be due to a lacking link between actors from the education and employment system (Bolli, Caves, Renold, \& Buergi, 2018; Caves, Ghisletta, Renold, $\&$ Kemper, 2019). However, all three formal education levels increase the probability to work in the formal sector.

Furthermore, the paper shows that the overall picture of the relationship between formal education and formal sector employment has remained similar over time. However, the strength of the relationship between completed primary and secondary education and formal sector employment has decreased over time.

While the relationship between tertiary-educated workers and wage-employment has decreased over time as well, the relationship has been stable for tertiary education and formal sector employment. This reflects the fact that a large share of workers with tertiary education work in the government-related sectors public administration, education and health, which are mostly located in the formal sector.

The main limitation of the study is that we cannot differentiate between the selection of companies and selection of individuals. While employment in the informal sector might be the last resort for some workers, it is an opportunity for other workers. Particularly for poor and deprived workers, the informal sector represents an important possibility to become an owner. Hence, future studies should evaluate in more detail whether informal sector employment is voluntary as suggested by Fossen and Büttner (2013). This would also provide more insights into which population groups choose informal sector employment and which population groups are in informal sector employment due to a lack of choice. This is particularly relevant as the results for workers with tertiary education suggest that working for the government might represent an important determinant of formal sector employment. Whether this is indeed the case should be analysed in more detail.

A related limitation consists of the fact that the paper estimates the relationship between formal education and formal sector employment rather than the causal effect on formal education. Hence, it remains ambiguous what causes changes in the relationship. One reason might be the changes in labour migration. Between 2008 and Journal of Education and Research, Vol. 9, No. 2, 2019 
2013, the number of labour permits increased from about 220'000 to about 560'000 (Ministry of Labour and Employment, 2016). While these numbers decreased to about $380^{\prime} 000$ in 2017, their magnitude illustrates the relevance of labour migration for Nepal. In order to test the relevance of this phenomenon for the results in this paper, we analyse whether our results differ between young and old individuals. We find little differences between young and old workers. This suggests that increasing labour migration is an unlikely explanation for our findings. Nevertheless, other sources of unobserved heterogeneity might exist, such as the lack of control variables for shortterm skill development and informal education activities. This concern is particularly relevant in Nepal, where informal and non-formal forms of human capital development are very relevant. Hence, future research should propose credible identification strategies to estimate these returns.

Data availability further limits the conclusions drawn from the empirical analysis. Different data sets can provide a varying picture, thereby highlighting the relevance of continuing the process of collecting the data of the AHHS. Furthermore, continuing to gather future data of the NLFS also helps to create consistent estimates across time. This is particularly important because the NLFS is the only data source that allows distinguishing formal sector employment and formal employment.

\section{Notes}

${ }^{1}$ For simplicity, the following discussions refer to the first year of the surveys only. For example, 1995/1996 is denoted as 1995.

${ }^{2}$ Unfortunately, data for informal jobs (Hussmanns 2004) are only available for 2008.

${ }^{3}$ Alternatively, we could -use a Logit model or assume that the error term is homoscedastic. This yields nearly the same results which can be obtained upon request from the authors.

${ }^{4}$ We use the command "margins" of Stata 15 (Williams, 2012).

${ }^{5}$ Interacting all control variables with year fixed effects yields nearly the same results which can be obtained from the authors upon request.

${ }^{6}$ Including additional year fixed effects yield nearly the same results that are available upon request.

${ }^{7}$ Corresponding tables of the estimates are available upon request from the authors.

${ }^{8}$ These estimates are available upon request from the authors.

${ }^{9}$ These estimates are available upon request from the authors. 
$70 \mid$ T. Bolli, M. N. Parajuli, \& U. Renold

\section{Acknowledgments}

We thank the Central Bureau of Statistics (CBS) Nepal for providing the data. We further thank the Swiss National Science Foundation and the Swiss Agency for Development and Cooperation for funding part of the research. We also thank Isabel Günther for comments on an earlier draft.

\section{ORCiD}

Thomas Bolli (D) https://orcid.org/0000-0002-7317-6862

Mahesh Nath Parajuli (D https://orcid.org/0000-0001-7917-7738

Ursula Renold (D https://orcid.org/0000-0003-4196-0019

\section{References}

Amin, M. (2010). Labor productivity in the informal sector: Necessity vs. opportunity firms. Washington, DC: World Bank. Retrieved from http://bitly.ws/9afo

Ai, C., \& Norton, E. C. (2003). Interaction terms in logit and probit models. Economics Letters, 80(1), 123-129.

Backes-Gellner, U., \& Werner, A. (2007). Entrepreneurial signaling via education: A success factor in innovative start-ups. Small Business Economics, 29(1/2), 173-190.

Becker, G. S. (1962). Investment in human capital: A theoretical analysis. Journal of Political Economy, 70(5), 9-49.

Brown, S., \& Sessions, J. G. (1999). Education and employment status: A test of the strong screening hypothesis in Italy. Economics of Education Review, 18(4), 397404.

Caves, K. M., Ghisletta, A., Renold, U., \& Kemper, J. (2019). Meeting in the middle TVET programs' education-employment linkage in developing contexts. $K O F$ Working Papers, 460.

Caves, K. M., \& Renold, U. (2018). Goal-setting for TVET reform: A framework for identifying the ideal system in Nepal. Journal of Education and Research, 8(1), 628. https://doi.org/10.3126/jer.v8i1.25477

Bolli, T., Caves, K. M., Renold, U., \& Buergi, J. (2018). Beyond employer engagement: measuring education-employment linkage in vocational education and training programmes. Journal of Vocational Education and Training, 70, 524-563.

Central Bureau of Statistics. (1996). Nepal living standards survey 1995-1996:

Statistical report: Main findings (Vols. 1-2). Kathmandu, Nepal: Author..

Journal of Education and Research, Vol. 9, No. 2, 2019 
Formal Education and Formal Employment in Nepal | 71

Central Bureau of Statistics. (1999). Nepal labour force survey 1998/99: Statistical report. Kathmandu, Nepal: Author.

Central Bureau of Statistics. (2004). Nepal living standards survey 2003/04: Statistical report: Main findings (Vols. 1-2). Kathmandu, Nepal: Author.

Central Bureau of Statistics. (2009). Report on the Nepal labour force survey 2008:

Statistical report. Kathmandu, Nepal: Author.

Central Bureau of Statistics. (2011). Nepal living standards survey 2010/11: Statistical report: Main findings (Vols. 1-2). Kathmandu, Nepal: Author.

Central Bureau of Statistics. (2015): Annual household survey 2013/14: Major findings. Kathmandu, Nepal: Author.

Central Bureau of Statistics. (2016): Annual household survey 2014/15: Major findings. Kathmandu, Nepal: Author.

De Soto, H. (1989). The other path: The invisible revolution in the third world. New York, NY: Harper and Row.

Dickson, P. H., Solomon, G. T., \& Weaver, K. M. (2008). Entrepreneurial selection and success: does education matter? Journal of Small Business and Enterprise Development, 15(2), 239-258.

Douhan, R., \& Van Praag, C. M. (2009). Entrepreneurship, wage employment and control in an occupational choice framework (IZA Discussion Paper 4211). Bonn, Germany: Institute for the Study of Labor.

Falco, P., Kerr, A., Rankin, N., Sandefur, J., \& Teal, F. (2011). The returns to formality and informality in urban Africa. Labour Economics, 18, S23-S31.

Fossen, F. M., \& Büttner, T. J. (2013). The returns to education for opportunity entrepreneurs, necessity entrepreneurs, and paid employees. Economics of Education Review, 37, 66-84.

European Training Foundation. (1999). Review of progress in vocational education and training reform of the candidate countries for accession to the European Union in the light of developments in European policy on vocational training. Turin, Italy: Author.

Günther, I., \& Launov, A. (2012). Informal employment in developing countries: Opportunity or last resort? Journal of Development Economics, 97(1), 88-98. Hart, K, (1973). Informal income opportunities and urban employment in Ghana. Journal of Modern African Studies, 11, 61-89. 
$72 \mid$ T. Bolli, M. N. Parajuli, \& U. Renold

Hanushek, E. A., \& Woessmann, L. (2008). The role of cognitive skills in economic development. Journal of Economic Literature, 46(3), 607-68.

Henley, A., Arabsheibani, G. R., \& Carneiro, F. G. (2009). On defining and measuring the informal sector: Evidence from Brazil. World Development, 37(5), 992-1003.

Hussmanns, R. (2004). Measuring the informal economy: From employment in the informal sector to informal employment (ILO Working Paper 53). Geneva, Switzerland: ILO.

International Labour Organization. (2013). Measuring informality: A statistical manual on the informal sector and informal employment. Geneva, Switzerland: Author.

Jah, K. K. (2002). Informal labour in the construction industry in Nepal (ILO Sectoral Activities Programme Working Paper 187). Geneva, Switzerland: ILO.

Kafle, N. P. (2013). Lived experiences of middle level leaders in the Nepali institutional schools. Journal of Education and Research, 3(2), 59-76.

Klieme, E., Avenarius, H., Baethge, M., Döbert, H., Hetmeier, H., Meister-Scheufelen, G., Rauschenbach, T., \& Wolter, A. (2006). Grundkonzeption der Bildungsberichterstattung in Deutschland [Basic concept of educational reporting in Germany]. Zeitschrift für Erziehungswissenschaft. Bildungs- und Sozialberichterstattung [Journal of Educational and Social Reporting], 6, 129-145.

Chair of Education Systems (2015). CES factbook education system Nepal. Retrieved from http://bitly.ws/9af4

Krueger, A. B., \& Lindahl, M. (2001). Education for growth: Why and for whom? Journal of Economic Literature, 39(4), 1101-1136.

Ministry of Labour and Employment. (2016). labour migration for employment: A status report for Nepal: 2014/2015. Kathmandu, Nepal: Author.

Nepal Law Commission. (2015). The constitution of Nepal. Retrieved from http://www.lawcommission.gov.np/en/category-prevailing-law-constitution

Parajuli, M. N. (2014). Goals of education: protecting and promoting divergence and sustainability. Journal of Education and Research, 4(1), 1-5.

Parker, S. C., \& Van Praag, C. M. (2006). Schooling, capital constraints and entrepreneurial performance: The endogenous triangle. Journal of Business and Economic Statistics, 24(4), 416-431.

Renold, U., \& Caves, K. M. (2017). Constitutional reform and its impact on TVET governance in Nepal. A report in support of developing understanding and finding the way forward for federalizing the TVET Sector in Nepal. First report in support

Journal of Education and Research, Vol. 9, No. 2, 2019 
Formal Education and Formal Employment in Nepal |73

of developing understanding and finding the way forward for federalising the TVET sector in Nepal. KOF Studies, 89.

Renold, U., Bolli, T., \& Caves, K. M. (2018). Constitutional reform and its impact on TVET governance in Nepal. Second report in support of developing understanding and finding the way forward for federalising the TVET sector in Nepal. KOF Studies, 114.

Sharma, T. N. (2008). Structures and mechanisms of community participation in school management. Journal of Education and Research, 1, 72-85.

Sharma, T. N. (2014). Education for rural transformation: The role of community learning centers in Nepal. Journal of Education and Research, 4(2), 87-101. Spence, M. (1973). Job market signaling. The Quarterly Journal of Economics, 87(3), 355-374.

Van Praag, C. M., Van Witteloostuijn, A., \& Van der Sluis, J. (2013). The higher returns to formal education for entrepreneurs versus employees. Small Business Economics, 40(2), 375-396.

Van der Sluis, J., Van Praag, M., \& Vijverberg, W. (2005). Entrepreneurship selection and performance: A meta-analysis of the impact of education in developing economies. The World Bank Economic Review, 19(2), 225-261.

Van der Sluis, J., Van Praag, M., \& Vijverberg, W. (2008). Education and entrepreneurship selection and performance: A review of the empirical literature. Journal of Economic Surveys, 22(5), 795-841.

Williams, R. (2012). Using the margins command to estimate and interpret adjusted predictions and marginal effects. The Stata Journal, 12(2), 308-331.

Wolpin, K. I. (1977). Education and screening. American Economic Review, 67(5), 949958.

Yu, D. (2012). Defining and measuring informal employment in South Africa.

Development Southern Africa, 29(1), 157-175.

\section{To cite this article:}

Bolli, T., Parajuli, M. N., \& Renold, U. (2019). Changes in the relationship between formal education and the formal employment sector in Nepal between 1995 and 2014. Journal of Education and Research, 9(2), 49-73. https://doi.org/10.3126/jer.v9i2.30462 